\title{
Association between a polymorphism of the $\alpha$-lactalbumin gene and milk production traits in Chinese Holstein cows
}

\author{
J.P. Zhou and C.H. Dong \\ Agricultural Science and Engineering Department, \\ Shandong Agriculture and Engineering University, Shandong, China \\ Corresponding author: C.H. Dong \\ E-mail: dch0007@163.com
}

Genet. Mol. Res. 12 (3): 3375-3382 (2013)

Received September 13, 2012

Accepted January 2, 2013

Published September 4, 2013

DOI http://dx.doi.org/10.4238/2013.September.4.3

\begin{abstract}
The traits particularly important for milk production include milk yield, protein percentage, fat percentage, and the somatic cell score. Alpha-lactalbumin ( $\alpha$-LA) is an important whey protein of cow milk, and is also present in the milk of many other mammalian species. In this study, we analyzed the genetic polymorphisms of the $\alpha$-LA gene and their relationship to milk production traits (milk yield, protein percentage, fat percentage, and somatic cell score) in Chinese Holstein cows. The goal of this study was to contribute further molecular genetic information related to dairy cattle, to determine the molecular markers that are most closely linked with milk production traits, and to provide a scientific basis for the improvement of economically relevant traits in cows. Fluorescence-based conformation-sensitive gel electrophoresis, DNA sequencing, and ligation detection reaction techniques were used to analyze genetic variations of the $\alpha$-LA gene (5'-UTR, exons 1, 2, 3, 4, and 3'-UTR) in 923 Chinese Holstein cows. One novel single nucleotide polymorphism (SNP), $\alpha$-LA2516, was identified in exon 4 of the $\alpha$-LA gene. Allele frequencies were as follows: T 0.674, C 0.326. Association analysis revealed that $\alpha$-LA2516 was not associated with milk yield,
\end{abstract}


protein percentage, fat percentage, or somatic cell score $(\mathrm{P}>0.05)$. These findings suggest that the SNP $\alpha$-LA2516 in the $\alpha$-LA gene likely does not have potential as a molecular marker for milk production traits in Chinese Holstein cows.

Key words: Chinese Holstein cows; Milk production traits; SNP; Alpha-lactalbumin gene; Association analysis

\section{INTRODUCTION}

Studies for improving milk production traits have been conducted for more than 100 years. However, traditional methods based on phenotype observations of cows and their progeny and kin are both time-consuming and expensive. With the advent of molecular techniques, greater productivity can be achieved by determining the potential of an animal even before phenotypes are expressed through the identification of genetic variants of any gene at the DNA level, independent of age and gender (Otaviano et al., 2005). Milk production traits in dairy cattle are governed mainly by genetic factors, whose variation can then be used as molecular markers for milk production traits (Ng-Kwai-Hang et al., 1990). Fluorescence-based conformation-sensitive gel electrophoresis (F-CSGE) was developed as a method of heteroduplex analysis to screen large multiexon genes for sequence variation. The use of F-CSGE techniques to find more genetic variants affecting milk production traits is valuable for the improvement of economic traits of dairy cattle.

The small milk protein $\alpha$-lactalbumin ( $\alpha$-LA) represents $2-5 \%$ of the overall composition of cow milk, and is the second major protein in bovine milk. $\alpha$-LA is a small, acidic, molten-globule, cation-binding milk protein, which has several important biological functions, such as lactose synthesis and $\mathrm{Ca}^{2+}$ binding (Lonnerdal and Glazier, 1985; Bleck et al., 1998). In addition, $\alpha$-LA has been linked to antimicrobial activity (Pellegrini et al., 1999; Kilara and Panyam, 2003), reduction of stress (Markus et al., 2000), immunomodulation (Brody, 2000; Cross and Gill, 2000), regulation of cell growth (Sternhagen and Allen, 2001), antiulcer activity (Matsumoto et al., 2001), and antihypertensive activity (Fitzgerald et al., 2004). However, its most important function is related to milk productivity in cows (Bleck and Bremel, 1993). In this study, we analyzed the genetic polymorphism of the $\alpha$-LA protein and its relationship with milk production traits in Chinese Holstein cows. The goal was to contribute further molecular genetic information related to dairy cattle, to find molecular markers that are most closely linked with milk production traits, and to provide a scientific basis for the improvement of economic traits.

\section{MATERIAL AND METHODS}

\section{Animals and sample collection}

Dairy cow $(\mathrm{N}=923)$ blood samples were collected from the No. 1 and 2 Jiabao Breeding Farm in the Shandong Province of China. The animals were kept in-house under constant rearing and feeding conditions. Genomic DNA was obtained from blood samples using a BioTeke Genomic DNA kit (BioTeke), which was used for single nucleotide polymorphism (SNP) discovery and association analyses. 


\section{Collection of milk production data from dairy cows}

Milk production data, including milk yield, protein percentage, fat percentage, and somatic cell score, were obtained from breeding data bank records of farms. Milk yield was weighed using an electronic scale. Somatic cell score was obtained using a Somacount 150 (Bentley), excluding any cases of sub-clinical mastitis from the samples. Fat and protein percentages were estimated using an infra-red milk analyzer.

\section{F-CSGE}

For the fluorescent polymerase chain reaction (PCR), each forward primer was labeled at the 5'-end with FAM fluorescent dye. PCRs were performed in a total reaction volume of $20 \mu \mathrm{L}$, containing $1 \mu \mathrm{L}$ DNA solution, $0.6 \mu \mathrm{L} 100 \mathrm{mM} \mathrm{MgCl}, 2 \mu \mathrm{L} 20 \mathrm{mM}$ dNTP, $0.4 \mu \mathrm{L}$ $5 \mathrm{pM}$ primer mixture, $0.4 \mu \mathrm{L} 5 \mathrm{X}$ Q-Solution, and $0.2 \mu \mathrm{L} 5 \mathrm{U} / \mu \mathrm{L}$ Qiagen HotStar Taq (Qiagen, Germany). The mixture was denatured at $95^{\circ} \mathrm{C}$ for $15 \mathrm{~min}$, followed by 35 cycles of denaturation for $30 \mathrm{~s}$ at $94^{\circ} \mathrm{C}$, annealing for $90 \mathrm{~s}$ (Table 1), and extension for $1 \mathrm{~min}$ at $72^{\circ} \mathrm{C}$, with a final extension of $7 \mathrm{~min}$ at $72^{\circ} \mathrm{C}$. PCR primers (Table 1) were designed according to the DNA sequence of Bos taurus (GenBank accession No. X06366). The 9 PCR fragments covered the 5 '-untranslated region (UTR), 4 coding regions, and the 3'-UTR of the $\alpha$-LA gene.

\begin{tabular}{|c|c|c|c|}
\hline Primer & Sequence (5'-3') & Fragment length (bp) & Annealing temperature $\left({ }^{\circ} \mathrm{C}\right)$ \\
\hline 5U1-up & GTGGCCTACTCTGAGGCTGT & 325 & 56 \\
\hline 5U1-low & ACTCAACCCAGGCATGAAAC & & \\
\hline 5U2-up & GACCACTCAACAAGGAACCAA & 348 & 56 \\
\hline 5U2-low & ССТTTCСТССССAGAATCTC & & \\
\hline 5U3-up & CCAAATGGGAAACAGGATCA & 301 & 56 \\
\hline 5U3-low & GATGCCTACCAGGAGCAGAG & & \\
\hline Exon 1-up & TGGTGACCCCATTTCAGAAT & 200 & 59 \\
\hline Exon 1-low & TGGGACAAAGCAAAATAGCA & & \\
\hline Exon 2-up & CATCCTTGTGAAATCTCTTTTTCAT & 250 & 59 \\
\hline Exon 2-low & TCCCAGGAGTAGGTTTCAGA & & \\
\hline Exon 3-up & TTTCTCACCCAGAAGGCAAC & 269 & 59 \\
\hline Exon 3-low & TAGTGCTGGGACGAAAGGAC & & \\
\hline Exon 4-up & GCCATGTGGCTAGGAAAGTC & 287 & 59 \\
\hline Exon 4-low & CAAGGGGGTACAAAGAAGCA & & \\
\hline 3U1-up & TGAACACCTGCTGTCTTTGC & 343 & 56 \\
\hline 3U1-low & ACCCATGGCCAGGTCTAC & & \\
\hline 3U2-up & GATTTTGAGTGGCTGGCTGT & 365 & 56 \\
\hline 3U2-low & GCAACCCACTCCATTGTTCT & & \\
\hline
\end{tabular}

To generate heteroduplexes, 20 samples were selected randomly. One PCR product was chosen as the probe, and other PCR products were mixed with this probe to generate heteroduplexes, using 6 graded steps of temperature reduction in a 9600-PCR cycle (Applied Biosystems, Foster City, CA, USA), as follows: $98^{\circ} \mathrm{C}$ for $5 \mathrm{~min} ; 98-90^{\circ} \mathrm{C}$ for $5 \mathrm{~min} ; 90-80^{\circ} \mathrm{C}$ for $5 \mathrm{~min} ; 80-75^{\circ} \mathrm{C}$ for $10 \mathrm{~min} ; 75-60^{\circ} \mathrm{C}$ for $10 \mathrm{~min} ; 60-40^{\circ} \mathrm{C}$ for $20 \mathrm{~min} ; 40-25^{\circ} \mathrm{C}$ for $20 \mathrm{~min}$.

After terminating PCR, samples were electrophoresed on $0.2-\mathrm{mm}$ thick $12 \%$ polyacrylamide gels, at a 99:1 ratio of acrylamide (BioRad, USA) to 1,2 bis-acryloylpiperazine (Fluka, Switzerland), and 15\% formamide (v/v) in 1X TBE buffer. The sample loading mix contained $0.5 \mu \mathrm{L}$ PCR product, $0.5 \mu \mathrm{L} 50 \mathrm{mg} / \mathrm{mL}$ dextran blue, and $0.5 \mu \mathrm{L}$ freshly deionized 
formamide. Samples (1.2-1.5 $\mu \mathrm{L})$ were separated on a standard ABI 377 sequencer using the $1 \mathrm{X} \mathrm{TBE}$ as the electrode buffer. Electrophoresis was performed at $2000 \mathrm{~V}$ for $4 \mathrm{~h}$ at $30^{\circ} \mathrm{C}$ in 1X TBE. Data analysis was conducted using the GeneMapper software (Applied Biosystems).

Once a subset of PCR products with aberrant CSGE patterns had been identified (Figure 1), their PCR products were reamplified using the same primers used for CSGE, and DNA was sequenced using the ABI 3730XL DNA Analyzer (Applied Biosystems).

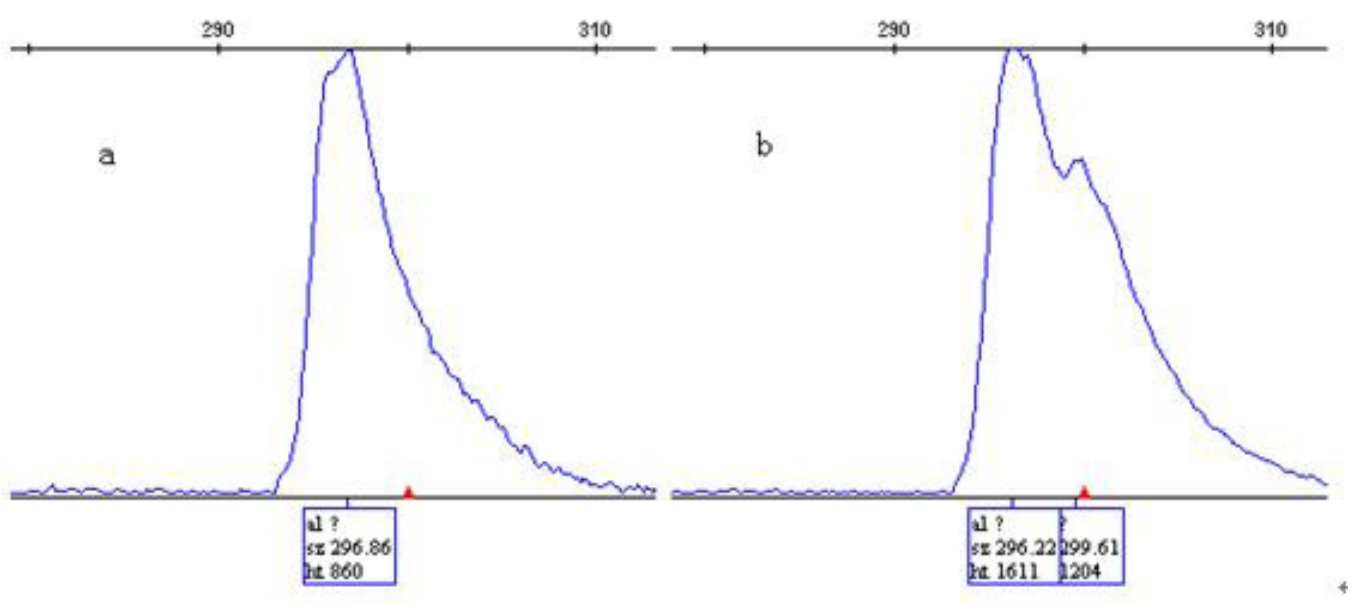

Figure 1. Fluorescence-based conformation-sensitive gel electrophoresis electropherograms of homo- and heterodupex. a. Homoduplex formed in the mixture of PCR products amplified from exon 4. b. Heteroduplex formed in the mixture of PCR products amplified from exon 4.

\section{Ligation detection reaction (LDR)}

According to the results of F-CSGE and DNA sequencing, one polymorphism ( $\alpha$ LA2516) was identified in exon 4 of the $\alpha$-LA gene in Chinese Holstein cows. Genotypes were detected using the LDR (Figure 2).

PCRs were performed by Gene Amp PCR Systems 9600 (Perkin-Elmer, Foster City, CA, USA) with the forward primer: 5'-AGCTGGATCAGTGGCTCTGT-3' and the reverse primer: 5'-GAGCAAGGGTCAAAAGTCCA-3'. PCR primers were designed to contain the $\alpha$-LA2516 polymorphism, and the PCR product was $230 \mathrm{bp}$. PCR was performed in a total reaction volume of $20 \mu \mathrm{L}$, containing $1 \mu \mathrm{L}$ DNA solution, $0.6 \mu \mathrm{L} 100 \mathrm{mM} \mathrm{MgCl}_{2}, 2 \mu \mathrm{L} 20 \mathrm{mM}$ dNTP, $0.4 \mu \mathrm{L} 5 \mathrm{pM}$ primer mixture, $0.4 \mu \mathrm{L} 4 \mathrm{X}$ Q-Solution, and $0.2 \mu \mathrm{L} 5 \mathrm{U} / \mu \mathrm{L}$ Qiagen HotStar Taq (Qiagen). The mixture was denatured at $95^{\circ} \mathrm{C}$ for $15 \mathrm{~min}$, followed by 35 cycles of denaturation for $30 \mathrm{~s}$ at $94^{\circ} \mathrm{C}$, annealing for $1 \mathrm{~min}$ at $59^{\circ} \mathrm{C}$, and extension for $1 \mathrm{~min}$ at $72^{\circ} \mathrm{C}$, with a final extension of $7 \mathrm{~min}$ at $72^{\circ} \mathrm{C}$. After this reaction, $2 \mu \mathrm{L}$ PCR products were electrophoresed on $3 \%$ agarose gel in $0.5 \mathrm{X}$ TBE buffer. The rest of the samples were stored at $-20^{\circ} \mathrm{C}$ until use.

The LDR probes were designed so that the 3'-position of each specific probe matched the discriminating nucleotide. The common probes were located immediately after the discriminating probes according to the corresponding target sequences. The common probes contained a phosphate in the 5'-terminal position with FAM dye at the 3'-end. The specific probes 
are shown in Table 2. The LDR was carried out in a final volume of $10 \mu \mathrm{L}$, containing $1 \mu \mathrm{L}$ 10X ligation buffer, $1 \mu \mathrm{L}$ probe mix, $0.05 \mu \mathrm{L} 40 \mathrm{U} / \mu \mathrm{L}$ ligase, $6.95 \mu \mathrm{L}$ deionized water, and 1 $\mu \mathrm{L}$ PCR products. The reaction mixture was denatured at $95^{\circ} \mathrm{C}$ for $2 \mathrm{~min}$, and the LDR was cycled for 35 rounds at $94^{\circ} \mathrm{C}$ for $30 \mathrm{~s}$ and at $60^{\circ} \mathrm{C}$ for $2 \mathrm{~min}$ in a thermocycler.

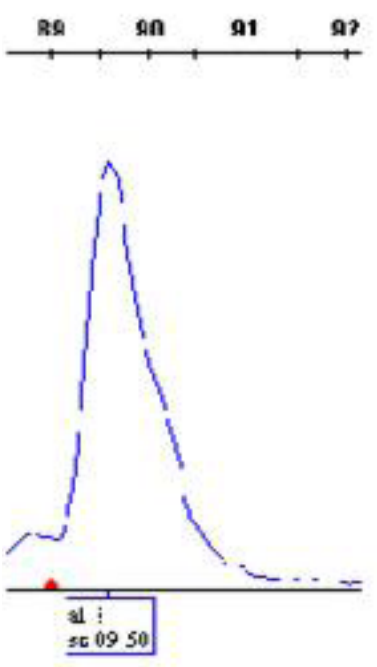

$\mathrm{CC}$
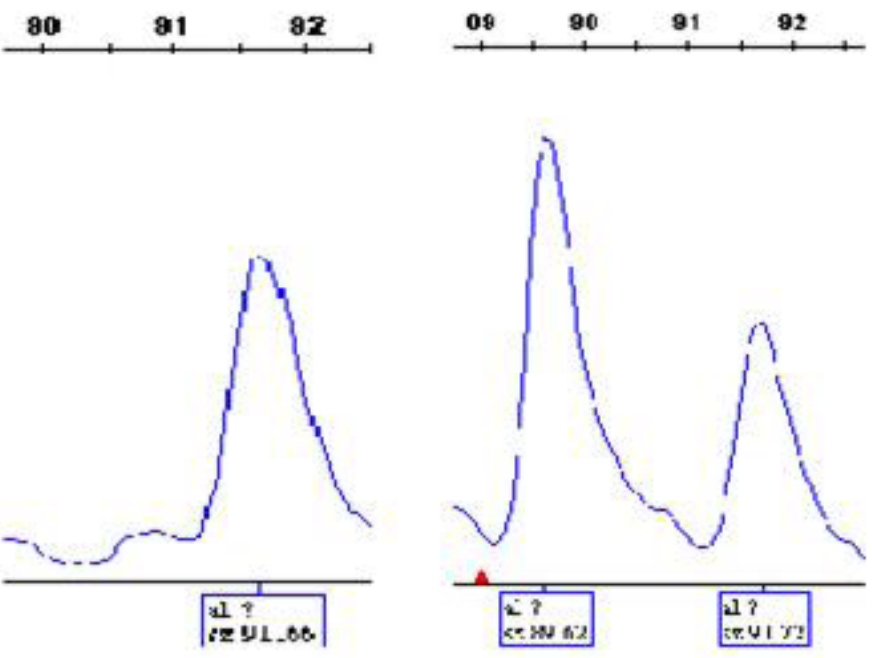

CT

Figure 2. Profile for ligation detection reaction in $\alpha$-LA2516 mutation for the $\alpha$-lactalbumin gene of Chinese Holstein cow.

Table 2. Probe sequences for ligation detection reaction (LDR).

\begin{tabular}{llc}
\hline Probe & Sequences $\left(5^{\prime}-3^{\prime}\right)$ & LDR length (bp) \\
\hline$\alpha$-LA2516_modify & P-GAAGCAGCAAAGACAGCAGGTGTTCTTTTTTTTTTTTTTTTTTTT-FAM & \\
$\alpha$-LA2516_C & TTTTTTTTTTTTTTTTTTTGAGTTCCAGGAACAGAAAGAGGACG & 90 \\
$\alpha$-LA2516_T & TTTTTTTTTTTTTTTTTTTTTTGAGTTCCAGGAACAGAAAGAGGACA & 92 \\
\hline
\end{tabular}

Confirmation of LDR typing of individuals carrying the $\alpha$-LA2516 mutation was achieved on an ABI PRISM-377 DNA sequencer (Applied Biosystems) according to the length of the LDR products. In the testing phase of the procedure, the success of the ligation was visualized with polyacrylamide gel electrophoresis. Mixtures containing $1 \mu \mathrm{L}$ ligation product, $1 \mu \mathrm{L}$ ABI GS-500 ROX fluorescence labeling molecular weight standard and $1 \mu \mathrm{L}$ formamide deionized loading buffer were denatured at $95^{\circ} \mathrm{C}$ for $2 \mathrm{~min}$, and shock cooled on ice. The mixtures were run at $3000 \mathrm{~V}$ for $2.5 \mathrm{~h}$ on $5 \%$ polyacrylamide gel with $5 \mathrm{M}$ urea.

\section{Statistical analysis}

Allele and genotype frequencies were determined by gene counting. Genotype distri- 
bution deviations from those expected at Hardy-Weinberg equilibrium were determined using the GENEPOP software.

The F-CSGE data analysis was performed using the GeneMapper software (Applied Biosystems), and the LDR data analysis was performed using the GENESCAN ${ }^{\mathrm{TM}} 672$ software. These 2 datasets were then compared in order to identify genotypes.

Associations of polymorphisms with milk production traits and comparative analysis of the expression pattern of the $\alpha$-LA gene between genotypes were subjected to general linear model analysis using the SAS software package (version 9.1.3). The mixed linear model was as follows:

$$
\mathrm{Y}=\mu+\mathrm{Ye}+\mathrm{A}+\mathrm{S}+\mathrm{G}+\mathrm{e}
$$

in which $Y$ is the value of each trait, $\mu$ is the population mean, $Y e$ is the fixed effect of year, $A$ is the fixed effect of age, $S$ is the random effect of sire, $G$ is a fixed effect corresponding to the genotype, and e is the random residual term. Significance of treatment comparisons was determined using P values of least-square mean differences (SAS 9.1.3).

\section{RESULTS}

\section{Analysis of $\alpha$-LA gene polymorphisms}

According to the polymorphism validation, there was one novel SNP ( $\alpha$-LA2516) in exon 4 of the $\alpha$-LA gene in Chinese Holstein cows (Figure 1). Sequencing revealed a single nucleotide substitution $\mathrm{C} \rightarrow \mathrm{T}(\alpha$-LA2516) at position 2516 of the $\alpha$-LA gene (Figure 3 ). The genotype TT occurred with the highest frequency, followed by TC and CC (Table 3 ). The allele T showed frequencies above $65 \%$ and was the dominant allele. The observed genotype frequency of the $\alpha$-LA2516 polymorphism was observed to be in Hardy-Weinberg equilibrium ( $\mathrm{P}>0.05)$.

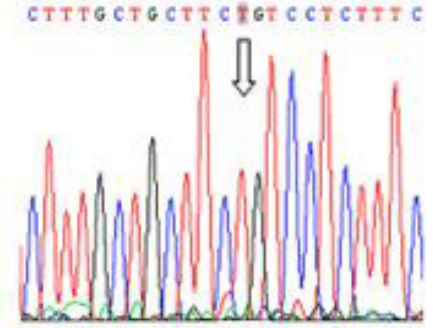

TT

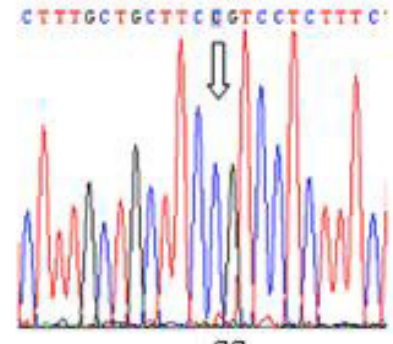

$\mathrm{CC}$

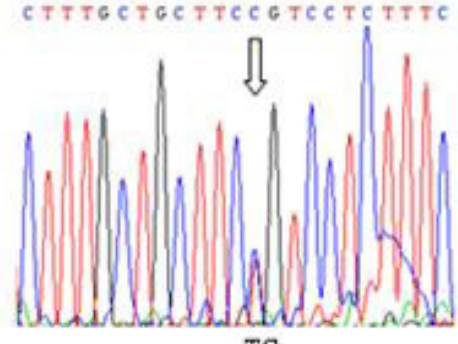

TC

Figure 3. Mutations for $\alpha$-lactalbumin in Chinese Holstein cows.

Table 3. Genotype frequencies of $\alpha$-lactalbumin in Chinese Holstein cows.

\begin{tabular}{|c|c|c|c|c|c|}
\hline SNP & Count & Genotype & Frequency & Allele & Frequency \\
\hline$\alpha$-LA2516 & 923 & $\begin{array}{l}\text { TT } \\
\text { TC } \\
\text { CC }\end{array}$ & $\begin{array}{l}0.453(418) \\
0.443(409) \\
0.104(96)\end{array}$ & $\begin{array}{l}\mathrm{T} \\
\mathrm{C}\end{array}$ & $\begin{array}{l}0.674 \\
0.326\end{array}$ \\
\hline
\end{tabular}




\section{Associations among genotype and milk production traits}

The results of associations between milk production traits and $\alpha$-LA2516 of the $\alpha$-LA gene are shown in Table 4. Based on this analysis, there were no significant associations between $\alpha$-LA2516 and milk yield, protein percentage, fat percentage, or somatic cell score (P > $0.05)$. In addition, there were no significant additive or dominance effects in milk production traits $(\mathrm{P}>0.05)$.

Table 4. Genotype frequencies of $\alpha$-lactalbumin in Chinese Holstein cows (means \pm SE).
\begin{tabular}{lcrccc}
\hline SNP & Genotype & Milk yield & Protein percentage & Fat percentage & Somatic cell score \\
\hline$\alpha$-LA2516 & TT & $6378.7 \pm 255.2$ & $3.00 \pm 0.06$ & $3.74 \pm 0.12$ & $4.17 \pm 0.23$ \\
& TC & $6425.7 \pm 239.8$ & $3.01 \pm 0.06$ & $3.72 \pm 0.11$ & $4.23 \pm 0.22$ \\
Additive effect & CC & $6395.3 \pm 318.2$ & $3.05 \pm 0.07$ & $3.76 \pm 0.15$ & $4.39 \pm 0.29$ \\
Dominant effect & & $8.3 \pm 126.8$ & $0.02 \pm 0.03$ & $0.01 \pm 0.06$ & $0.11 \pm 0.12$ \\
& & $38.7 \pm 171.6$ & $-0.01 \pm 0.04$ & $-0.03 \pm 0.08$ & $-0.08 \pm 0.16$ \\
\hline
\end{tabular}

\section{DISCUSSION}

The current study was performed to characterize the polymorphisms of the $\alpha$-LA gene in Chinese Holstein cows. We further investigated associations between different $\alpha$-LA genotypes and milk production traits in Chinese Holstein cows. $\alpha$-LA is an important whey protein in cow milk, and is also present in the milk of many other mammalian species. It interacts with UDP-galactosyltransferase to form the lactose synthetase and was thus described as a key protein for lactogenesis (Hayssen and Blackburn, 1985). At the same time, $\alpha$-LA is considered to be the bovine milk protein that is most lactation specific and its expression is used as a lactation specific marker in both mammary expellant and in cell culture systems (Vega et al., 1988). The $\alpha$-LA gene appears to be a promising candidate gene, because it may regulate important functions in milk production (Bleck and Bremel, 1993). Several polymorphic sites have been detected within the $\alpha$-LA gene in cattle and goats (Jain et al., 2009; Ma et al., 2010). However, in the current study, scans of the full coding region, 5'-UTR, and 3'-UTR of the gene, revealed one novel SNP in exon 4 of Chinese Holstein cows. The genotypes TT and TC occurred with the highest frequency, suggesting that these genotypes may eventually be induced in long-term artificial selection practices for increased milk production.

Several previous studies have examined the associations of the SNPs of $\alpha$-LA with milk production traits. However, there is no information available regarding the association of this novel SNP ( $\alpha$-LA2516). Previous studies have revealed that SNPs in $\alpha$-LA potentially alter gene expression and may be associated with differences in milk yield and quality (Mao, 1994; Ramesha, 2002). However, according to the association analysis conducted in the present study, the novel SNP ( $\alpha$-LA2516), located in exon 4 of the $\alpha$-LA gene, was not associated with milk yield, protein percentage, fat percentage, or somatic cell score, suggesting that the SNP $\alpha$-LA2516 does not significantly affect the milk production traits evaluated. These results were consistent with observations in goats (Ma et al., 2010) and buffalo (Dayal et al., 2009). Further studies using larger populations and other dairy cattle breeds are needed to confirm these results. 


\section{CONCLUSIONS}

In conclusion, one polymorphism ( $\alpha$-LA2516) was identified in exon 4 of the $\alpha$-LA gene of Chinese Holstein cows. The present study showed that the $\alpha$-LA2516 polymorphism had no association with milk yield, protein percentage, fat percentage, or somatic cell score. More research is needed in order to determine if the $\alpha$-LA2516 polymorphism of the $\alpha$-LA gene could be useful as a potential molecular marker for milk production traits in Chinese Holstein cows.

\section{ACKNOWLEDGMENTS}

Research supported by the Shandong Province Key Technologies R\&D Program (\#2010GNC10932), China. We thank the Breeding Farms of Jiabao for providing cashmere goat and production trait data, and also the Shandong Academy of Agricultural Sciences for their help.

\section{REFERENCES}

Bleck GT and Bremel RD (1993). Correlation of the $\alpha$-lactalbumin $(+15)$ polymorphism to milk production and milk composition of Holsteins. J. Dairy Sci. 76: 2292-2298.

Bleck GT, White BR, Miller DJ and Wheeler MB (1998). Production of bovine $\alpha$-lactalbumin in the milk of transgenic pigs. J. Anim. Sci. 76: 3072-3078.

Brody EP (2000). Biological activities of bovine glycomacropeptide. Br. J. Nutr. 84 (Suppl 1): S39-S46.

Cross ML and Gill HS (2000). Immunomodulatory properties of milk. Br. J. Nutr. 84 (Suppl 1): S81-S89.

Dayal S, Bhattacharya TK, Kaushik P and Singh SR (2009). Genetic typing of the $\alpha$-lactalbumin gene and its association with milk production and constituent traits in Indian riverine buffaloes. Buffalo Bull. 28: 11-17.

Fitzgerald RJ, Murray BA and Walsh DJ (2004). Hypotensive peptides from milk proteins. J. Nutr. 134: 980S-988S.

Hayssen V and Blackburn DG (1985). $\alpha$-Lactalbumin and the origins of lactation. Evolution 39: 1147-1149.

Jain A, Gour DS, Bisen PS, Prashant, et al. (2009). Single nucleotide polymorphism (SNP) in $\alpha$-lactalbumin gene of Indian Jamunapari breed of Capra hircus. Small Rumin. Res. 82: 156-160.

Kilara A and Panyam D (2003). Peptides from milk proteins and their properties. Crit. Rev. Food Sci. Nutr. 43: 607-633.

Lonnerdal B and Glazier C (1985). Calcium binding by $\alpha$-lactalbumin in human milk and bovine milk. J. Nutr. 115: 1209-1216.

Ma RN, Deng CJ, Zhang XM, Yue XP, et al. (2010). A novel SNP of $\alpha$-lactalbumin gene in Chinese dairy goats. Mol. Biol. 44: 536-540.

Mao FC (1994). A bovine $\alpha$-lactalbumin gene Mn/l restriction fragment length polymorphism. J. Anim. Sci. 72: 529.

Markus CR, Olivier B, Panhuysen GE, Van Der Gugten J, et al. (2000). The bovine protein $\alpha$-lactalbumin increases the plasma ratio of tryptophan to the other large neutral amino acids, and in vulnerable subjects raises brain serotonin activity, reduces cortisol concentration, and improves mood under stress. Am. J. Clin. Nutr. 71: 1536-1544.

Matsumoto H, Shimokawa Y, Ushida Y, Toida T, et al. (2001). New biological function of bovine $\alpha$-lactalbumin: protective effect against ethanol- and stress-induced gastric mucosal injury in rats. Biosci. Biotechnol. Biochem. 65: 1104-1111.

Ng-Kwai-Hang KF, Monardes HG and Hayes JF (1990). Association between genetic polymorphism of milk proteins and production traits during three lactations. J. Dairy Sci. 73: 3414-3420.

Otaviano AR, Tonhati H, Sena JAD and Cerón Muñoz MF (2005). Kappa-casein gene study with molecular markers in female buffaloes (Bubalus bubalis). Genet. Mol. Biol. 28: 237-241.

Pellegrini A, Thomas U, Bramaz N, Hunziker P, et al. (1999). Isolation and identification of three bactericidal domains in the bovine $\alpha$-lactalbumin molecule. Biochim. Biophys. Acta 1426: 439-448.

Ramesha KP (2002). Single Nucleotide Polymorphisms in $\alpha$-Lactalbumin Gene in Cattle. JNC visiting fellow report submitted to Jawaharlal Nehru Centre for Advanced Scientific, Bangalore.

Sternhagen LG and Allen JC (2001). Growth rates of a human colon adenocarcinoma cell line are regulated by the milk protein $\alpha$-lactalbumin. Adv. Exp. Med. Biol. 501: 115-120.

Vega JR, Sheffield LG and Bremel RD (1988). Effect of prolactin on a-Lactalbumin synthesis in bovine mammary explants of pregnant heifers with different genetic potential. J. Dairy Sci. (Suppl 1): 174. 